Article

\title{
Geothermal Resource Exploration by Stream pH Mapping in Mutsu Hiuchi Dake Volcano, Japan
}

\author{
Yota Suzuki ${ }^{1, *}$, Seiichiro Ioka ${ }^{2}$ and Hirofumi Muraoka ${ }^{2}$ \\ 1 Graduate School of Science and Technology, Hirosaki University, 3 Bunkyo-cho, Hirosaki, \\ Aomori 036-8561, Japan \\ 2 North Japan Research Institute for Sustainable Energy, Hirosaki University, 2-1-3 Matsubara, \\ Aomori 030-0813, Japan; ioka@hirosaki-u.ac.jp (S.I.); hiro@hirosaki-u.ac.jp (H.M.) \\ * Correspondence: h15ds204@hirosaki-u.ac.jp; Tel.: +81-17-735-3363
}

Academic Editor: Francesco Calise

Received: 25 May 2017; Accepted: 7 July 2017; Published: 16 July 2017

\begin{abstract}
Although $\mathrm{pH}$ measurements of hot spring water are taken in conventional geothermal resource research, previous studies have seldom created $\mathrm{pH}$ distribution maps of stream and spring waters for an entire geothermal field as a technique for geothermal exploration. In this study, a $\mathrm{pH}$ distribution map was created by measuring stream and spring water $\mathrm{pH}$ at 75 sites in the Mutsu Hiuchi Dake geothermal field, Japan. Areas of abnormally high $\mathrm{pH}$ were detected in midstream sections of the Ohaka and Koaka rivers; these matched the location of the Mutsu Hiuchi Dake East Slope Fault, which is believed to have formed a geothermal reservoir. The abnormally high $\mathrm{pH}$ zone is attributed to the trapping of rising volcanic gases in a mature geothermal reservoir with neutral geothermal water. This causes the gas to dissolve and prevents it from reaching the surface. Thus, the mapping of stream water $\mathrm{pH}$ distribution in a geothermal field could provide a new and effective method for estimating the locations of geothermal reservoirs. As the proposed method does not require laboratory analysis, and is more temporally and economically efficient than conventional methods, it might help to promote geothermal development in inaccessible and remote regions.
\end{abstract}

Keywords: geothermal energy; geothermal exploration; fault; $\mathrm{pH}$ map; Mutsu Hiuchi Dake; Japan

\section{Introduction}

Globally, the installed capacity of geothermal power is increasing each year, and it had reached 12,729 MW as of 2015. In particular, recent years have seen an increasing demand to develop geothermal power in inaccessible and remote regions [1]. The installed capacity of geothermal power in Japan was $519 \mathrm{MW}$ as of 2015 [1], which is still far behind its huge amounts of geothermal resource potentials, considering the numerous volcanoes mostly located in inaccessible highlands and remote islands. Consequently, there is worldwide interest in developing new, temporally and economically efficient exploration methods that might contribute to the promotion of geothermal power in such regions.

The most important issue in geothermal resource exploration is to efficiently find a geothermal reservoir that has resources suitable for power generation. Generally, the early stages of geothermal resource exploration consist of surface and well surveys, of which surface surveys are further categorized into geological surveys, geochemical surveys, and geophysical exploration [2-4]. Since there is presently no decisive exploration method to determine where a reservoir is located, the results of these various methods require comprehensive analysis and evaluation.

Geochemical surveys are used as an effective method for understanding the characteristics of geothermal fluids in many geothermal surveys, and there have been many studies on this method $[5,6]$. Conventional methods focus on hot spring water and fumaroles. In particular, the $\mathrm{pH}$ measurement of hot spring water provides important insights into basic chemical composition when conducting 
geothermal surveys. However, previous studies have seldom analyzed the $\mathrm{pH}$ of stream and spring waters distributed throughout an entire survey area for the purpose of geothermal reservoir exploration. For instance, a classical paper developed a conceptual model of geothermal fluid systems on high relief andesite volcanoes from low $\mathrm{pH}$ water at the summit fumarole area to near-neutral $\mathrm{pH}$ water at the foot area. However, actual stream $\mathrm{pH}$ maps of andesite volcanoes were not necessarily shown [7]. Some $\mathrm{pH}$ contour maps are confined to the production field because studies limit the acidity of production reservoirs to avoid the problem of corrosion and erosion [8]. Another $\mathrm{pH}$ contour map providing data on 7203 hot springs covering almost all of Japan indicates that low $\mathrm{pH}$ anomalies coincide exactly with Quaternary volcanoes; however, the scale of this map is too low for exploration [9]. To the best of the authors' knowledge, $\mathrm{pH}$ mapping for the purpose of geothermal reservoir exploration has thus been quite rare.

Classical articles on geothermal exploration reiterate that the goal of geothermal exploration is to find high-temperature subsurface reservoirs composed of near-neutral $\mathrm{pH}$ alkali chloride water [7]. Such water is also called mature water because it undergoes long-lived water-rock interaction processes in deep reservoirs under chemical equilibria [10]. These processes generally result in near-neutral $\mathrm{pH}$ chloride water buffered by the interaction with host rocks [7]. Considering geothermal systems in high relief andesite volcanoes, high-temperature reservoirs are expected near the summits because they are close to magmatic heat sources. However, high relief andesite volcanoes result in a scarcity of mature chloride water discharges except at some distance from fumaroles near the summits [7]. This leads to a discrepancy between the high-temperature demand and neutral $\mathrm{pH}$ water reservoir demand. This discrepancy can be resolved only by detecting anomaly zones of near-neutral $\mathrm{pH}$ chloride water near the summits. One simple and rapid means of finding such anomaly zones is the $\mathrm{pH}$ mapping of stream and spring water.

In the present study, the $\mathrm{pH}$ of stream and spring water was measured at 75 sites within the Mutsu Hiuchi Dake geothermal field to create a $\mathrm{pH}$ distribution map. The study shows that mapping the $\mathrm{pH}$ distribution could provide a new and effective method for estimating the locations of geothermal reservoirs. The $\mathrm{pH}$ value of stream water is clearly influenced by several factors [11], but this study emphasizes the phenomenological and practical efficiency of $\mathrm{pH}$ mapping as an extraordinarily prompt exploration method. To establish stream $\mathrm{pH}$ mapping as a more reliable method, case studies in other geothermal fields are required. Some such case studies will soon be described in a separate paper that will include the methodology of stream $\mathrm{pH}$ mapping. This paper focuses primarily on presenting how a geologically identified fault can be geochemically elucidated as a prospective near-neutral $\mathrm{pH}$ reservoir by the proposed stream $\mathrm{pH}$ mapping method.

\section{Mutsu Hiuchi Dake Geothermal Field}

Since the Great East Japan Earthquake of 11 March 2011, there has been increasing momentum to expand the implementation of geothermal power generation in Japan. Japan is endowed with many geothermal resources in Hokkaido, and in the Tohoku and Kyushu regions [12], and rich geothermal resources are also expected to be found in Aomori prefecture (Tohoku). There are several Quaternary volcanoes within the area of Aomori prefecture [13]. The most prospective geothermal field is located near Mutsu Hiuchi Dake volcano [14,15]. This region is suitable for geothermal development as it lies outside the national park area and is therefore not subject to regulations on such forms of development (Figure 1). 


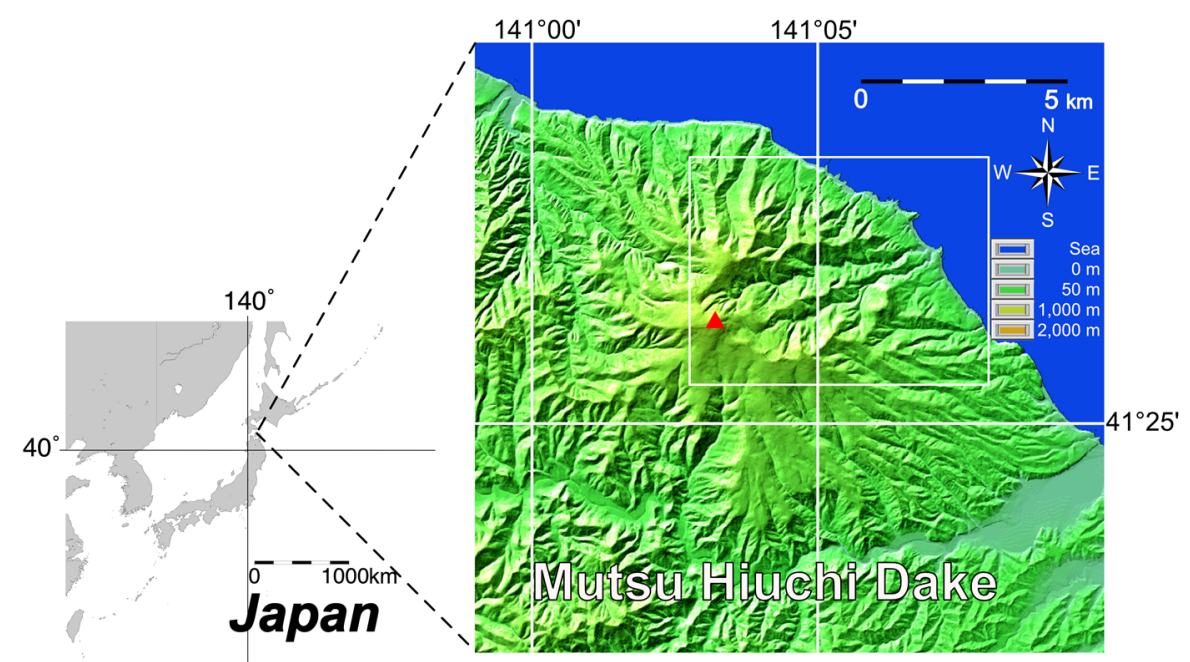

Figure 1. The location of Mutsu Hiuchi Dake volcano in Japan, and a schematic map of the terrain; the red triangle indicates the summit of Mutsu Hiuchi Dake volcano. The white square indicates the location shown in Figures 2-5. This map employs the Geospatial Information Authority of Japan's base map information for numerical elevation model (10 m mesh).

The Mutsu Hiuchi Dake volcano, which is the northernmost Quaternary volcano in Honshu, is a gently sloped stratovolcano with an elevation of $781.3 \mathrm{~m}$, and the formation of the erosion caldera is likened to a horseshoe with an opening to the northeast [16]. The vicinity of Mutsu Hiuchi Dake volcano has been the subject of several surveys for geothermal development in 1975, 1976, and from 1983 to 1985, including multiple drillings for geothermal survey wells [17]. The highest recorded temperature of hot water was $228.5^{\circ} \mathrm{C}$ at $1700 \mathrm{~m}$ depth within the well N59-SK-6 (Figure 2) [17]. The area was selected for the present study because it shows several signs of geothermal activity, such as alteration zones and fumaroles relating to hydrothermal alteration $[17,18]$, and is therefore considered suitable for geothermal development. The area within the erosion caldera is subsequently referred to as the Mutsu Hiuchi Dake geothermal field. Water from steam condensation and hot water observed at N59-SK-6 both showed acidity, precipitation of minerals primarily consisting of sulfur and pyrite, and significant damage to the casing pipe was confirmed [17]. In order to successfully develop geothermal energy in the Mutsu Hiuchi Dake geothermal field, the most important task would be to discover a mature, neutral $\mathrm{pH}$ water reservoir to avoid corrosion and erosion of the well casing, pipe lines, and turbine. 


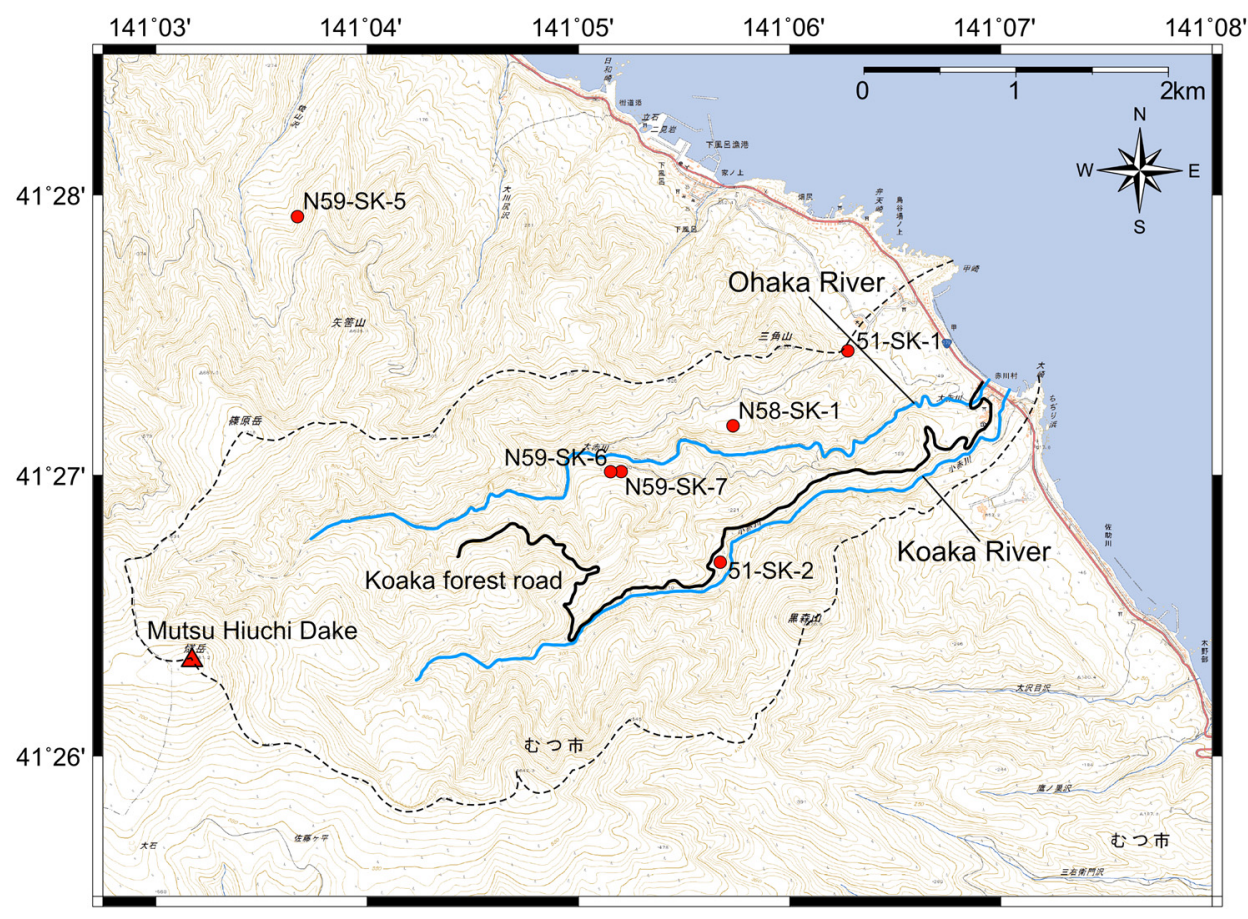

Figure 2. Topographic map of Mutsu Hiuchi Dake geothermal field: The red triangle indicates the summit of the Mutsu Hiuchi Dake volcano, and the red circles indicate geothermal wells drilled in previous surveys. The dotted lines represent the erosion caldera as mapped by Uemura and Saito [16]. In creating this map, the 1:25,000 scale map (of Shimofuro) published by the Geospatial Information Authority of Japan was used.

\section{The Discovery of Mutsu Hiuchi Dake East Slope Fault}

A fault, which cuts across the Mutsu Hiuchi Dake geothermal field, was not known during the geothermal development survey conducted from 1983 to 1985, but was discovered by our surveys conducted in recent years (Figure 3) $[19,20]$. This fault is called the Mutsu Hiuchi Dake East Slope Fault. It is a normal fault that runs NNW-SSE and tilts to the east at a steep angle of $61^{\circ}$ to $77^{\circ}$. The thickness of its foliated fault gouge reaches up to $4 \mathrm{~m}$ (Figure 3). Mutsu Hiuchi Dake East Slope Fault is located closer to the summit-and hence closer to the center of the heat source-than are the geothermal wells drilled during previous surveys (Figures 2 and 3), which heightens the expectation that this location could be endowed with a geothermal resource of even higher temperature than those previously observed. Additionally, it is known that there are hydrothermal alteration zones relating to geothermal activities scattered across the Mutsu Hiuchi Dake geothermal field (Figure 3) $[17,18]$. Tomiyama et al. conducted detailed surveys of alteration zones in the Mutsu Hiuchi Dake geothermal field, and specified the distribution of silicified alteration zones (Figure 3) [18]. The sections displaying the greatest silicified alterations were located across the Koaka forest road and midstream areas of the Ohaka and Koaka rivers, coinciding with the location of the Mutsu Hiuchi Dake East Slope Fault. This finding indicates the possibility that the Mutsu Hiuchi Dake East Slope Fault had provided conduits for the rising of geothermal water. Furthermore, as the Mutsu Hiuchi Dake East Slope Fault displays the characteristics of a normal fault, it is expected to have relatively high permeability and high flow rate of geothermal water. Based on these points, there is a high chance that the Mutsu Hiuchi Dake East Slope Fault has formed a geothermal reservoir, and thus might be an important fault for geothermal development. 


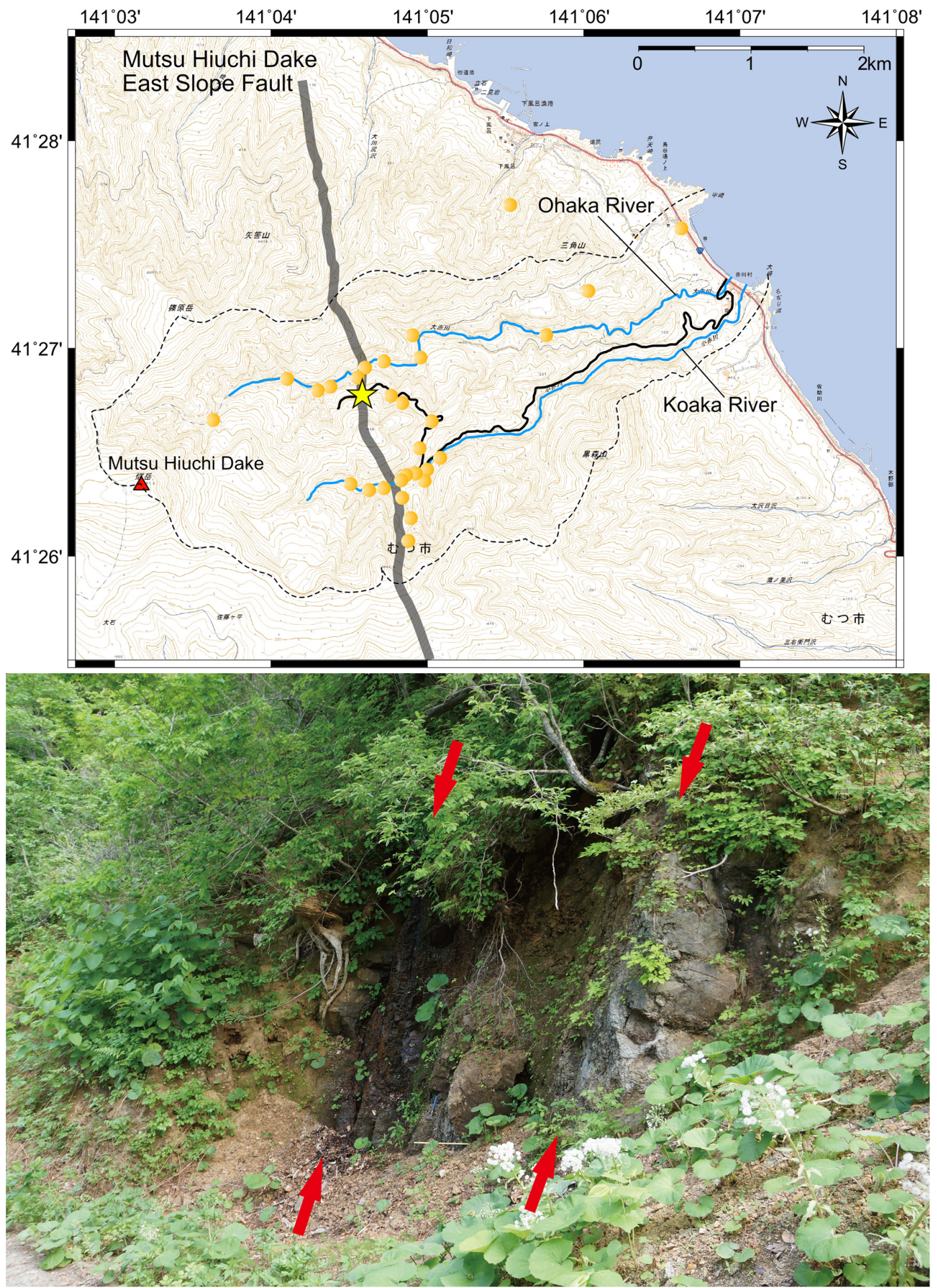

Figure 3. Top: Map showing the location of the Mutsu Hiuchi Dake East Slope Fault. The yellow circle indicates the location of silicified alteration zones as indicated by Tomiyama et al. [18]. The red triangle shows the location of the summit of Mutsu Hiuchi Dake volcano. The dotted lines represent the erosion caldera as mapped by Uemura and Saito [16]. In creating this map, the 1:25,000 scale map (of Shimofuro) published by the Geospatial Information Authority of Japan was used. Bottom: Photograph of the fault outcrop, its location is marked with a yellow star in the map above. The scale of the photo is indicated by the hammer and the yellow $1 \mathrm{~m}$ ruler in the lower-central portion of the photo. A 4-m thick foliated fault gouge is observed between arrows. 


\section{4. $\mathrm{pH}$ Distribution in Stream and Spring Water}

To construct the distribution map, $\mathrm{pH}$ was measured at 46 points in stream water, 26 points in cold spring water, and three points in hot spring water within the Mutsu Hiuchi Dake geothermal field. Spring and stream water $\mathrm{pH}$ was determined at the sampling site using a temperature-compensated electronic portable $\mathrm{pH}$ meter (model HM-20P, DKK-TOA Co. (Tokyo, Japan); instrument accuracy $\pm 0.02 \mathrm{pH}$ ). The $\mathrm{pH}$ electrode was calibrated with buffer solutions prepared from powder reagents of $\mathrm{pH}$ standard solutions with a $\mathrm{pH}$ accuracy of \pm 0.05 (Code No. 150-4 and 150-7, Horiba Ltd., Kyoto, Japan).

When measuring spring water $\mathrm{pH}$, the electrode was dipped directly into the location from where the water was outflowing. Where there was insufficient water to dip the electrode directly, the $\mathrm{pH}$ was measured by collecting the water into a beaker, which was rinsed three times using the specific spring water present at each sampling site. When measuring stream $\mathrm{pH}$, we selected spots closest to the source of the water where an actual flow could be seen, and measured by directly dipping the electrode into that water.

The $\mathrm{pH}$ values of the obtained samples are listed in Table 1 , and the resulting $\mathrm{pH}$ distribution map is shown in Figure 4. The distribution map was created using GMT (Generic Mapping Tools 4.5.9), and the values were contoured by smoothing at 100-m intervals [21]. The tension factor was set to 0.3 .

The $\mathrm{pH}$ ranged from 2.48 (site 62) to 7.85 (site 21). Points with low $\mathrm{pH}$ values were concentrated in the upstream areas of the Ohaka and Koaka rivers. In general, there was a tendency for $\mathrm{pH}$ levels to be lower closer to the summit of the volcano, and to increase at sites further from the summit.

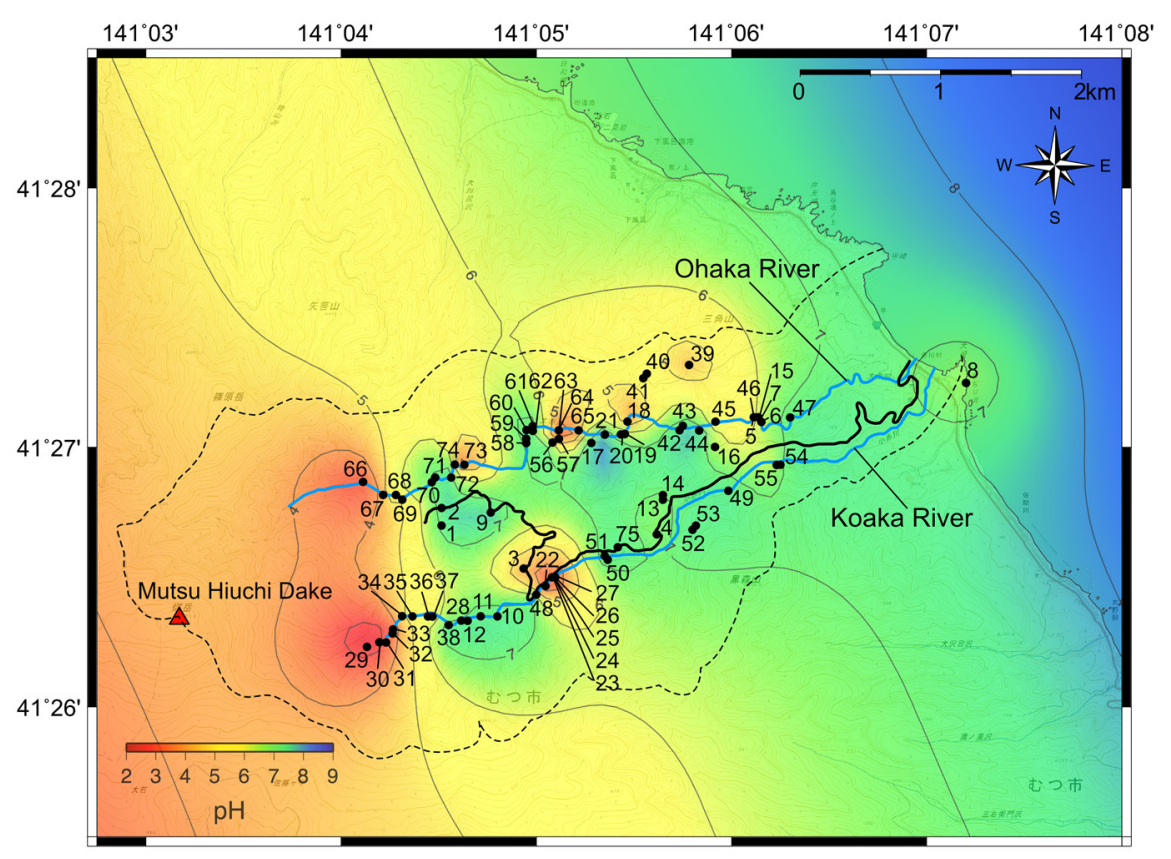

Figure 4. Distribution map of water $\mathrm{pH}$ in the Mutsu Hiuchi Dake geothermal field. The red triangle indicates the summit of the Mutsu Hiuchi Dake volcano. The black circles indicate data sampling points, and their numbers correspond to those in Table 1. The dotted lines represent the erosion caldera as mapped by Uemura and Saito [16]. In creating this map, the 1:25,000 scale map (of Shimofuro) published by the Geospatial Information Authority of Japan was used. 
Table 1. Water samples obtained in the Mutsu Hiuchi Dake geothermal field: Sample number, water type, sampling date, site location, and water $\mathrm{pH}$.

\begin{tabular}{|c|c|c|c|c|c|}
\hline No. & Water Type & Sampling Date & Longitude & Latitude & $\mathrm{pH}$ \\
\hline 1 & Spring water & 3 June 2014 & $141^{\circ} 4^{\prime} 31^{\prime \prime} \mathrm{E}$ & $41^{\circ} 26^{\prime} 42^{\prime \prime} \mathrm{N}$ & 7.39 \\
\hline 2 & Stream water & 3 June 2014 & $141^{\circ} 4^{\prime} 31^{\prime \prime} \mathrm{E}$ & $41^{\circ} 26^{\prime} 46^{\prime \prime} \mathrm{N}$ & 7.49 \\
\hline 3 & Stream water & 3 June 2014 & $141^{\circ} 4^{\prime} 56^{\prime \prime} \mathrm{E}$ & $41^{\circ} 2^{\circ} 6^{\prime} 32^{\prime \prime} \mathrm{N}$ & 3.95 \\
\hline 4 & Stream water & 3 June 2014 & $141^{\circ} 5^{\prime} 37^{\prime \prime} \mathrm{E}$ & $41^{\circ} 26^{\prime} 40^{\prime \prime} \mathrm{N}$ & 6.69 \\
\hline 5 & Hot Spring & 25 November 2015 & $141^{\circ} 6^{\prime} 8^{\prime \prime} \mathrm{E}$ & $41^{\circ} 27^{\prime} 7^{\prime \prime} \mathrm{N}$ & 6.03 \\
\hline 6 & Hot Spring & 4 June 2014 & $141^{\circ} 6^{\prime} 9^{\prime \prime} \mathrm{E}$ & $41^{\circ} 27^{\prime} 6^{\prime \prime} \mathrm{N}$ & 6.05 \\
\hline 7 & Hot Spring & 4 June 2014 & $141^{\circ} 6^{\prime} 9^{\prime \prime} \mathrm{E}$ & $41^{\circ} 27^{\prime} 6^{\prime \prime} \mathrm{N}$ & 6.08 \\
\hline 8 & Spring water & 20 August 2014 & $141^{\circ} 7^{\prime} 12^{\prime \prime} \mathrm{E}$ & $41^{\circ} 27^{\prime} 15^{\prime \prime} \mathrm{N}$ & 6.44 \\
\hline 9 & Stream water & 30 July 2015 & $141^{\circ} 4^{\prime} 46^{\prime \prime} \mathrm{E}$ & $41^{\circ} 26^{\prime} 45^{\prime \prime} \mathrm{N}$ & 7.68 \\
\hline 10 & Stream water & 3 August 2015 & $141^{\circ} 4^{\prime} 48^{\prime \prime} \mathrm{E}$ & $41^{\circ} 26^{\prime} 21^{\prime \prime} \mathrm{N}$ & 7.34 \\
\hline 11 & Stream water & 3 August 2015 & $141^{\circ} 4^{\prime} 43^{\prime \prime} \mathrm{E}$ & $41^{\circ} 26^{\prime} 21^{\prime \prime} \mathrm{N}$ & 7.40 \\
\hline 12 & Spring water & 3 August 2015 & $141^{\circ} 4^{\prime} 39^{\prime \prime} \mathrm{E}$ & $41^{\circ} 26^{\prime} 20^{\prime \prime} \mathrm{N}$ & 6.56 \\
\hline 13 & Stream water & 3 August 2015 & $141^{\circ} 5^{\prime} 39^{\prime \prime} \mathrm{E}$ & $41^{\circ} 26^{\prime} 48^{\prime \prime} \mathrm{N}$ & 6.78 \\
\hline 14 & Stream water & 3 August 2015 & $141^{\circ} 5^{\prime} 39^{\prime \prime} \mathrm{E}$ & $41^{\circ} 26^{\prime} 49^{\prime \prime} \mathrm{N}$ & 7.02 \\
\hline 15 & Stream water & 4 August 2015 & $141^{\circ} 6^{\prime} 8^{\prime \prime} \mathrm{E}$ & $41^{\circ} 27^{\prime} 7^{\prime \prime} \mathrm{N}$ & 7.56 \\
\hline 16 & Stream water & 28 August 2015 & $141^{\circ} 5^{\prime} 55^{\prime \prime} \mathrm{E}$ & $41^{\circ} 26^{\prime} 60^{\prime \prime} \mathrm{N}$ & 6.36 \\
\hline 17 & Stream water & 28 August 2015 & $141^{\circ} 5^{\prime} 17^{\prime \prime} \mathrm{E}$ & $41^{\circ} 27^{\prime} 1^{\prime \prime} \mathrm{N}$ & 7.70 \\
\hline 18 & Spring water & 14 September 2015 & $141^{\circ} 5^{\prime} 28^{\prime \prime} \mathrm{E}$ & $41^{\circ} 27^{\prime} 6^{\prime \prime} \mathrm{N}$ & 4.13 \\
\hline 19 & Spring water & 14 September 2015 & $141^{\circ} 5^{\prime} 27^{\prime \prime} \mathrm{E}$ & $41^{\circ} 27^{\prime} 3^{\prime \prime} \mathrm{N}$ & 6.75 \\
\hline 20 & Spring water & 14 September 2015 & $141^{\circ} 5^{\prime} 26^{\prime \prime} \mathrm{E}$ & $41^{\circ} 27^{\prime} 3^{\prime \prime} \mathrm{N}$ & 6.43 \\
\hline 21 & Stream water & 14 September 2015 & $141^{\circ} 5^{\prime} 21^{\prime \prime} \mathrm{E}$ & $41^{\circ} 27^{\prime} 3^{\prime \prime} \mathrm{N}$ & 7.85 \\
\hline 22 & Spring water & 26 April 2016 & $141^{\circ} 5^{\prime} 3^{\prime \prime} \mathrm{E}$ & $41^{\circ} 26^{\prime} 28^{\prime \prime} \mathrm{N}$ & 3.27 \\
\hline 23 & Stream water & 26 April 2016 & $141^{\circ} 5^{\prime} 6^{\prime \prime} \mathrm{E}$ & $41^{\circ} 26^{\prime} 30^{\prime \prime} \mathrm{N}$ & 3.09 \\
\hline 24 & Spring water & 26 April 2016 & $141^{\circ} 5^{\prime} 5^{\prime \prime} \mathrm{E}$ & $41^{\circ} 26^{\prime} 30^{\prime \prime} \mathrm{N}$ & 5.69 \\
\hline 25 & Spring water & 26 April 2016 & $141^{\circ} 5^{\prime} 5^{\prime \prime} \mathrm{E}$ & $41^{\circ} 26^{\prime} 30^{\prime \prime} \mathrm{N}$ & 2.97 \\
\hline 26 & Spring water & 26 April 2016 & $141^{\circ} 5^{\prime} 5^{\prime \prime} \mathrm{E}$ & $41^{\circ} 26^{\prime} 30^{\prime \prime} \mathrm{N}$ & 3.42 \\
\hline 27 & Spring water & 26 April 2016 & $141^{\circ} 5^{\prime} 6^{\prime \prime} \mathrm{E}$ & $41^{\circ} 26^{\prime} 30^{\prime \prime} \mathrm{N}$ & 3.67 \\
\hline 28 & Stream water & 27 April 2016 & $141^{\circ} 4^{\prime} 37^{\prime \prime} \mathrm{E}$ & $41^{\circ} 26^{\prime} 20^{\prime \prime} \mathrm{N}$ & 7.40 \\
\hline 29 & Spring water & 27 April 2016 & $141^{\circ} 4^{\prime} 8^{\prime \prime} \mathrm{E}$ & $41^{\circ} 26^{\prime} 14^{\prime \prime} \mathrm{N}$ & 2.63 \\
\hline 30 & Spring water & 27 April 2016 & $141^{\circ} 4^{\prime} 12^{\prime \prime} \mathrm{E}$ & $41^{\circ} 26^{\prime} 15^{\prime \prime} \mathrm{N}$ & 2.73 \\
\hline 31 & Spring water & 27 April 2016 & $141^{\circ} 4^{\prime} 14^{\prime \prime} \mathrm{E}$ & $41^{\circ} 26^{\prime} 15^{\prime \prime} \mathrm{N}$ & 3.35 \\
\hline 32 & Spring water & 27 April 2016 & $141^{\circ} 4^{\prime} 16^{\prime \prime} \mathrm{E}$ & $41^{\circ} 26^{\prime} 17^{\prime \prime} \mathrm{N}$ & 3.05 \\
\hline 33 & Stream water & 27 April 2016 & $141^{\circ} 4^{\prime} 16^{\prime \prime} \mathrm{E}$ & $41^{\circ} 26^{\prime} 18^{\prime \prime} \mathrm{N}$ & 3.59 \\
\hline 34 & Spring water & 27 April 2016 & $141^{\circ} 4^{\prime} 19^{\prime \prime} \mathrm{E}$ & $41^{\circ} 26^{\prime} 21^{\prime \prime} \mathrm{N}$ & 7.02 \\
\hline 35 & Spring water & 27 April 2016 & $141^{\circ} 4^{\prime} 22^{\prime \prime} \mathrm{E}$ & $41^{\circ} 26^{\prime} 21^{\prime \prime} \mathrm{N}$ & 3.38 \\
\hline 36 & Spring water & 19 May 2016 & $141^{\circ} 4^{\prime} 27^{\prime \prime} \mathrm{E}$ & $41^{\circ} 26^{\prime} 21^{\prime \prime} \mathrm{N}$ & 3.44 \\
\hline 37 & Stream water & 19 May 2016 & $141^{\circ} 4^{\prime} 28^{\prime \prime} \mathrm{E}$ & $41^{\circ} 26^{\prime} 21^{\prime \prime} \mathrm{N}$ & 7.02 \\
\hline 38 & Stream water & 19 May 2016 & $141^{\circ} 4^{\prime} 33^{\prime \prime} \mathrm{E}$ & $41^{\circ} 26^{\prime} 19^{\prime \prime} \mathrm{N}$ & 7.48 \\
\hline 39 & Stream water & 7 June 2016 & $141^{\circ} 5^{\prime} 47^{\prime \prime} \mathrm{E}$ & $41^{\circ} 27^{\prime} 19^{\prime \prime} \mathrm{N}$ & 4.48 \\
\hline 40 & Spring water & 7 June 2016 & $141^{\circ} 5^{\prime} 34^{\prime \prime} \mathrm{E}$ & $41^{\circ} 27^{\prime} 17^{\prime \prime} \mathrm{N}$ & 3.49 \\
\hline 41 & Stream water & 7 June 2016 & $141^{\circ} 5^{\prime} 33^{\prime \prime} \mathrm{E}$ & $41^{\circ} 27^{\prime} 16^{\prime \prime} \mathrm{N}$ & 7.26 \\
\hline 42 & Spring water & 8 June 2016 & $141^{\circ} 5^{\prime} 44^{\prime \prime} \mathrm{E}$ & $41^{\circ} 27^{\prime} 4^{\prime \prime} \mathrm{N}$ & 7.59 \\
\hline 43 & Spring water & 8 June 2016 & $141^{\circ} 5^{\prime} 45^{\prime \prime} \mathrm{E}$ & $41^{\circ} 27^{\prime} 5^{\prime \prime} \mathrm{N}$ & 7.57 \\
\hline 44 & Spring water & 8 June 2016 & $141^{\circ} 5^{\prime} 50^{\prime \prime} \mathrm{E}$ & $41^{\circ} 27^{\prime} 4^{\prime \prime} \mathrm{N}$ & 7.72 \\
\hline 45 & Stream water & 8 June 2016 & $141^{\circ} 5^{\prime} 55^{\prime \prime} \mathrm{E}$ & $41^{\circ} 27^{\prime} 6^{\prime \prime} \mathrm{N}$ & 5.24 \\
\hline 46 & Spring water & 15 June 2016 & $141^{\circ} 6^{\prime} 7^{\prime \prime} \mathrm{E}$ & $41^{\circ} 27^{\prime} 7^{\prime \prime} \mathrm{N}$ & 5.66 \\
\hline 47 & Stream water & 15 June 2016 & $141^{\circ} 6^{\prime} 18^{\prime \prime} \mathrm{E}$ & $41^{\circ} 27^{\prime} 7^{\prime \prime} \mathrm{N}$ & 7.36 \\
\hline 48 & Stream water & 7 July 2016 & $141^{\circ} 5^{\prime} 0^{\prime \prime} \mathrm{E}$ & $41^{\circ} 26^{\prime} 26^{\prime \prime} \mathrm{N}$ & 6.88 \\
\hline 49 & Stream water & 7 July 2016 & $141^{\circ} 5^{\prime} 59^{\prime \prime} \mathrm{E}$ & $41^{\circ} 26^{\prime} 50^{\prime \prime} \mathrm{N}$ & 7.45 \\
\hline 50 & Stream water & 8 July 2016 & $141^{\circ} 5^{\prime} 22^{\prime \prime} \mathrm{E}$ & $41^{\circ} 26^{\prime} 34^{\prime \prime} \mathrm{N}$ & 7.44 \\
\hline
\end{tabular}


Table 1. Cont.

\begin{tabular}{|c|c|c|c|c|c|}
\hline No. & Water Type & Sampling Date & Longitude & Latitude & $\mathrm{pH}$ \\
\hline 51 & Stream water & 8 July 2016 & $141^{\circ} 5^{\prime} 21^{\prime \prime} \mathrm{E}$ & $41^{\circ} 26^{\prime} 35^{\prime \prime} \mathrm{N}$ & 7.42 \\
\hline 52 & Stream water & 8 July 2016 & $141^{\circ} 5^{\prime} 48^{\prime \prime} \mathrm{E}$ & $41^{\circ} 26^{\prime} 41^{\prime \prime} \mathrm{N}$ & 7.49 \\
\hline 53 & Stream water & 8 July 2016 & $141^{\circ} 5^{\prime} 49^{\prime \prime} \mathrm{E}$ & $41^{\circ} 26^{\prime} 42^{\prime \prime} \mathrm{N}$ & 7.25 \\
\hline 54 & Stream water & 8 July 2016 & $141^{\circ} 6^{\prime} 15^{\prime \prime} \mathrm{E}$ & $41^{\circ} 26^{\prime} 56^{\prime \prime} \mathrm{N}$ & 7.10 \\
\hline 55 & Stream water & 8 July 2016 & $141^{\circ} 6^{\prime} 14^{\prime \prime} \mathrm{E}$ & $41^{\circ} 26^{\prime} 56^{\prime \prime} \mathrm{N}$ & 6.24 \\
\hline 56 & Stream water & 12 July 2016 & $141^{\circ} 5^{\prime} 5^{\prime \prime} \mathrm{E}$ & $41^{\circ} 27^{\prime} 1^{\prime \prime} \mathrm{N}$ & 7.04 \\
\hline 57 & Stream water & 12 July 2016 & $141^{\circ} 5^{\prime} 7^{\prime \prime} \mathrm{E}$ & $41^{\circ} 27^{\prime} 2^{\prime \prime} \mathrm{N}$ & 6.94 \\
\hline 58 & Stream water & 13 July 2016 & $141^{\circ} 4^{\prime} 57^{\prime \prime} \mathrm{E}$ & $41^{\circ} 27^{\prime} 1^{\prime \prime} \mathrm{N}$ & 7.03 \\
\hline 59 & Spring water & 13 July 2016 & $141^{\circ} 4^{\prime} 57^{\prime \prime} \mathrm{E}$ & $41^{\circ} 27^{\prime} 2^{\prime \prime} \mathrm{N}$ & 7.76 \\
\hline 60 & Stream water & 13 July 2016 & $141^{\circ} 4^{\prime} 57^{\prime \prime} \mathrm{E}$ & $41^{\circ} 27^{\prime} 4^{\prime \prime} \mathrm{N}$ & 7.50 \\
\hline 61 & Stream water & 13 July 2016 & $141^{\circ} 4^{\prime} 59^{\prime \prime} \mathrm{E}$ & $41^{\circ} 27^{\prime} 5^{\prime \prime} \mathrm{N}$ & 7.31 \\
\hline 62 & Spring water & 13 July 2016 & $141^{\circ} 4^{\prime} 59^{\prime \prime} \mathrm{E}$ & $41^{\circ} 27^{\prime} 4^{\prime \prime} \mathrm{N}$ & 2.48 \\
\hline 63 & Stream water & 13 July 2016 & $141^{\circ} 5^{\prime} 7^{\prime \prime} \mathrm{E}$ & $41^{\circ} 27^{\prime} 4^{\prime \prime} \mathrm{N}$ & 2.98 \\
\hline 64 & Stream water & 13 July 2016 & $141^{\circ} 5^{\prime} 7^{\prime \prime} \mathrm{E}$ & $41^{\circ} 27^{\prime} 4^{\prime \prime} \mathrm{N}$ & 2.88 \\
\hline 65 & Stream water & 13 July 2016 & $141^{\circ} 5^{\prime} 13^{\prime \prime} \mathrm{E}$ & $41^{\circ} 27^{\prime} 4^{\prime \prime} \mathrm{N}$ & 4.02 \\
\hline 66 & Stream water & 22 July 2016 & $141^{\circ} 4^{\prime} 7^{\prime \prime} \mathrm{E}$ & $41^{\circ} 26^{\prime} 52^{\prime \prime} \mathrm{N}$ & 3.17 \\
\hline 67 & Stream water & 22 July 2016 & $141^{\circ} 4^{\prime} 13^{\prime \prime} \mathrm{E}$ & $41^{\circ} 26^{\prime} 49^{\prime \prime} \mathrm{N}$ & 3.85 \\
\hline 68 & Stream water & 22 July 2016 & $141^{\circ} 4^{\prime} 17^{\prime \prime} \mathrm{E}$ & $41^{\circ} 26^{\prime} 49^{\prime \prime} \mathrm{N}$ & 6.90 \\
\hline 69 & Stream water & 22 July 2016 & $141^{\circ} 4^{\prime} 19^{\prime \prime} \mathrm{E}$ & $41^{\circ} 26^{\prime} 48^{\prime \prime} \mathrm{N}$ & 4.79 \\
\hline 70 & Stream water & 22 July 2016 & $141^{\circ} 4^{\prime} 28^{\prime \prime} \mathrm{E}$ & $41^{\circ} 26^{\prime} 52^{\prime \prime} \mathrm{N}$ & 6.72 \\
\hline 71 & Stream water & 22 July 2016 & $141^{\circ} 4^{\prime} 29^{\prime \prime} \mathrm{E}$ & $41^{\circ} 26^{\prime} 53^{\prime \prime} \mathrm{N}$ & 7.25 \\
\hline 72 & Stream water & 22 July 2016 & $141^{\circ} 4^{\prime} 34^{\prime \prime} \mathrm{E}$ & $41^{\circ} 26^{\prime} 53^{\prime \prime} \mathrm{N}$ & 7.55 \\
\hline 73 & Spring water & 10 October 2016 & $141^{\circ} 4^{\prime} 38^{\prime \prime} \mathrm{E}$ & $41^{\circ} 26^{\prime} 56^{\prime \prime} \mathrm{N}$ & 3.18 \\
\hline 74 & Stream water & 10 October 2016 & $141^{\circ} 4^{\prime} 35^{\prime \prime} \mathrm{E}$ & $41^{\circ} 26^{\prime} 56^{\prime \prime} \mathrm{N}$ & 6.92 \\
\hline 75 & Stream water & 10 October 2016 & $141^{\circ} 5^{\prime} 25^{\prime \prime} \mathrm{E}$ & $41^{\circ} 26^{\prime} 37^{\prime \prime} \mathrm{N}$ & 7.35 \\
\hline
\end{tabular}

\section{Discussion: pH Mapping as a New Geothermal Exploration Method}

The distribution map showed an overall tendency for lower $\mathrm{pH}$ closer to the summit, and higher $\mathrm{pH}$ further from the summit. In addition to the different types of fluids encountered in a high enthalpy geothermal system analyzed in Reference [22], the authors would like to propose the following interpretation to the observed surface waters $\mathrm{pH}$ distribution. Since volcanic gases actively rise near the summit (i.e., near the center of geothermal areas), fumaroles may appear at the ground surface, and volcanic gases dissolve into the stream water, thereby lowering the water $\mathrm{pH}$. Conversely, with increasing distance from the summit, the effect of volcanic gases lessen and $\mathrm{pH}$ levels gradually increase. This is consistent with a widely accepted classical geothermal fluid structure model of high relief andesite volcanoes [7]. On the whole, the Mutsu Hiuchi Dake geothermal field appears to follow this general tendency in the actual $\mathrm{pH}$ map (Figure 4). However, the actual $\mathrm{pH}$ map exhibits a sporadic pattern (Figure 4), where some areas of lower $\mathrm{pH}$ and others of higher $\mathrm{pH}$ exist. All the patterns are controlled by the permeability distribution. Some permeable spots contribute to rising volcanic gases and other permeable spots contribute to hot water discharge and cold water recharge. The three-dimensional permeability distribution is extremely difficult to determine and, therefore, all $\mathrm{pH}$ variations could not be completely explained. However, a relatively wide neutral $\mathrm{pH}$ anomaly zone with $\mathrm{pH}$ ranging from 6.56 to 7.68 could be found near the midstream of the Ohaka and Koaka rivers, as seen in the data sampling points $1,2,9,10,11,12,28,38,70,71$, and 72, extending NNW-SSE. The locations of the neutral $\mathrm{pH}$ anomaly zone correspond to the Mutsu Hiuchi Dake East Slope Fault (Figure 5). 


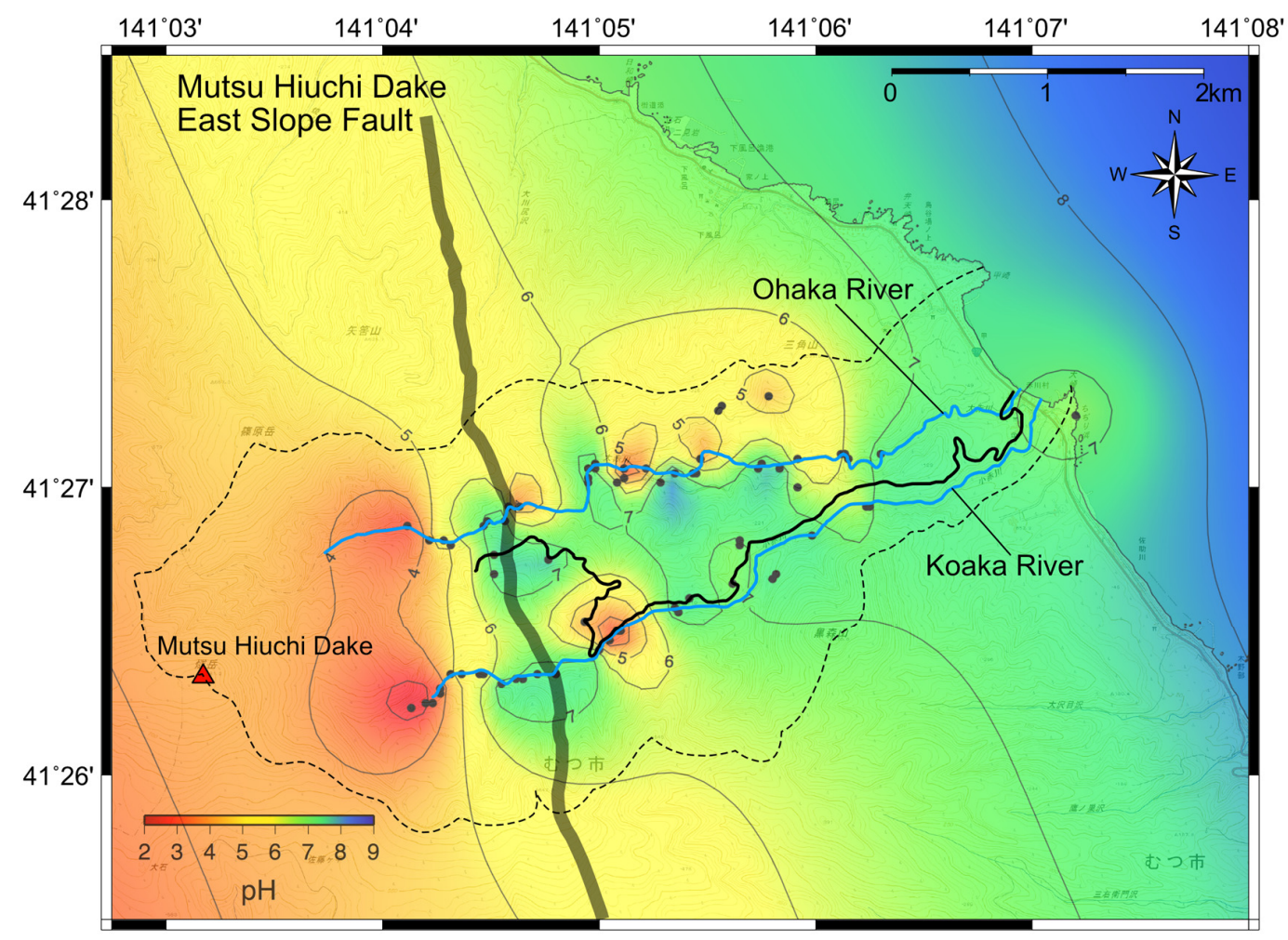

Figure 5. The $\mathrm{pH}$ distribution of stream and spring water in the Mutsu Hiuchi Dake geothermal field and the Mutsu Hiuchi Dake East Slope Fault. The red triangle indicates the summit of Mutsu Hiuchi Dake volcano. The dotted lines represent the erosion caldera as mapped by Uemura and Saito [16]. In creating this map, the 1:25,000 scale map (of Shimofuro) published by the Geospatial Information Authority of Japan was used.

The locations of stream and spring water anomalies of higher $\mathrm{pH}$ coincided with the Mutsu Hiuchi Dake East Slope Fault, even near the summit of Mutsu Hiuchi Dake volcano. This can be explained by the shadow effect of rising volcanic gases due to the presence of a geothermal reservoir (Figure 6). If a geothermal reservoir exists underground, the volcanic gases rising from deep underground will not reach the surface because they will be trapped and dissolved into the geothermal water of the reservoir. Consequently, the overlying stream waters would be unaffected by the volcanic gases, and would instead retain the neutral state of surface water originating from rainwater and shallow groundwater, as it flows in from its vicinity, which appears as abnormal areas in terms of higher $\mathrm{pH}$ levels in contrast to the general trend observed in the area. Shimada [23] previously pointed out that, in areas where rising volcanic gases are identified, there is almost no chance of finding a geothermal reservoir deep underground because the voluminous hot water reservoir tends to feed the rising volcanic gases [23]. Therefore, the $\mathrm{pH}$ distribution map for stream water within the Mutsu Hiuchi Dake geothermal field might indicate the possibility that the Mutsu Hiuchi Dake East Slope Fault has formed a neutral, mature hydrothermal system underground.

In general, volcanic gases are indicators of active magmatism and therefore indicators of potential geothermal heat sources at the regional scale. However, at more detailed scales, such as those used during the reservoir exploration stage, shadow zones of volcanic gases are rather prospective indicators in terms of finding mature near-neutral $\mathrm{pH}$ chloride water reservoirs. In this study, a large-scale fault was fortunately found before the $\mathrm{pH}$ mapping was conducted. A more common exploration process might be to identify neutral $\mathrm{pH}$ anomalies first by $\mathrm{pH}$ mapping and then by determining objective permeable bodies, such as the fault identified here. Permeable bodies usually consist of faults, but columnar jointed sheets and dikes as well as fractured formations may also play a role in reservoirs. 


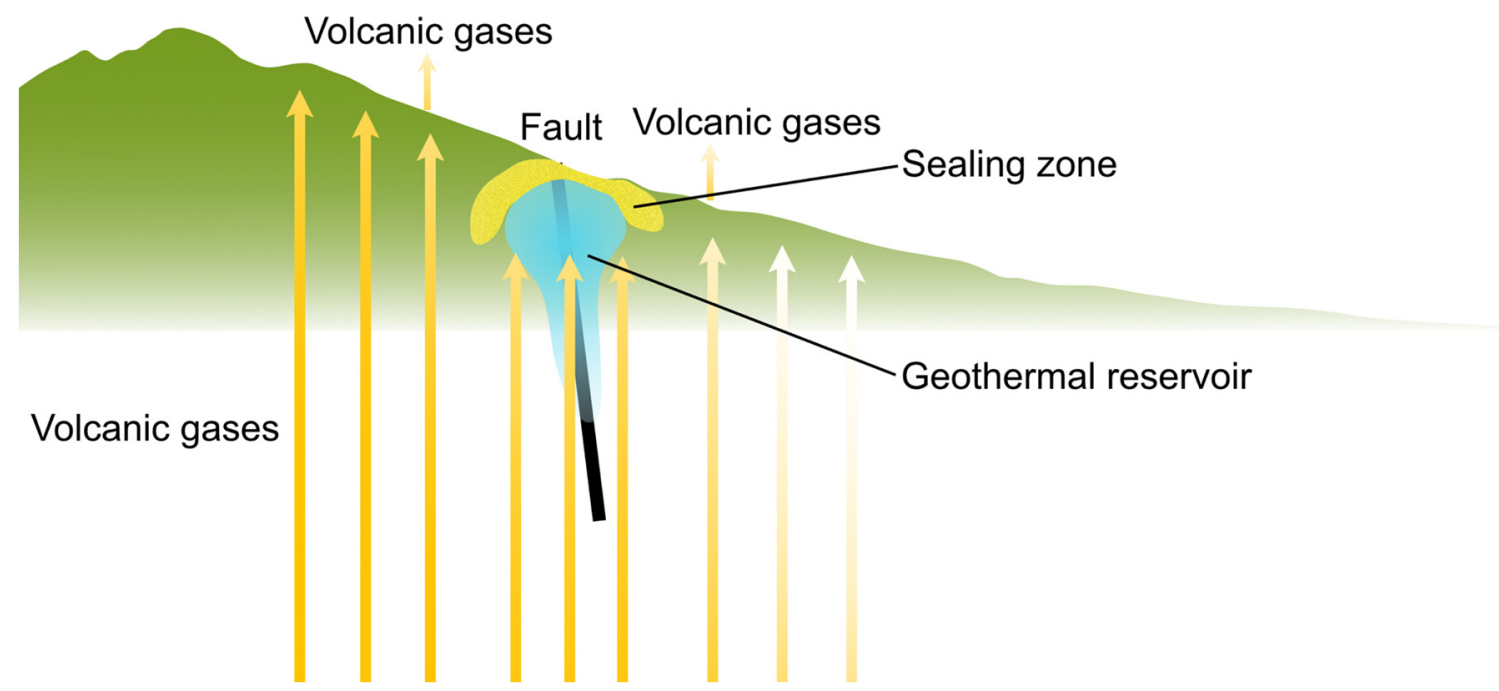

Figure 6. Schematic diagram of the shadow effect of volcanic gases due to the geothermal reservoir.

Thus, these findings indicate that mapping the distribution of stream and spring water $\mathrm{pH}$ in a geothermal field could help to identify geothermal reservoirs containing neutral, high-temperature water suitable for geothermal development. In other geochemical exploration methods as represented by geothermometry, the sample collected from the sites would have to be brought back to the laboratory to be analyzed $[5,6]$. In contrast, the proposed method requires only a simple $\mathrm{pH}$ meter for on-site analysis, and is therefore temporally and economically efficient. Consequently, as a new geothermal exploration technique, the mapping of stream and spring water $\mathrm{pH}$ distribution would likely contribute to the promotion of geothermal development in inaccessible and remote regions.

\section{Conclusions}

The $\mathrm{pH}$ of stream and spring waters was measured at 75 sites within the Mutsu Hiuchi Dake geothermal field to create a $\mathrm{pH}$ distribution map. Overall, the results showed a trend toward lower $\mathrm{pH}$ near the summit, and higher $\mathrm{pH}$ further from the summit. However, in contrast to the overall trend, areas of abnormally higher $\mathrm{pH}$ were identified between the midstream of the Ohaka and Koaka rivers, extending in the NNE-SSW direction. These locations matched the Mutsu Hiuchi Dake East Slope Fault, which is suspected to have formed a geothermal reservoir underground. The findings indicate that mapping the $\mathrm{pH}$ distribution of stream and spring waters could serve as a new geothermal exploration method for estimating the locations of subsurface geothermal reservoirs. Because the proposed mapping technique is temporally and economically efficient compared to conventional methods, it might promote geothermal development, especially in regions where access is limited.

Acknowledgments: This work was supported by Grant-in-Aid for JSPS Fellows Grant No. 15J10106 and JSPS KAKENHI Grant No. 26281053. We thank Editage (www.editage.jp) for English language editing.

Author Contributions: Yota Suzuki is the principal investigator, and drafted the first manuscript and all the figures. Seiichiro Ioka advised on hydrology. Hirofumi Muraoka advised on geology. All authors carried out of field work, read and approved the final manuscript.

Conflicts of Interest: The authors declare no conflicts of interest.

\section{References}

1. Bertani, R. Geothermal power generation in the world 2010-2014 update report. Geothermics 2016, 60, 31-43. [CrossRef]

2. Publication Committee of Geothermal Energy Handbook of the Geothermal Research Society of Japan. Geothermal Energy Handbook; Ohmsha: Tokyo, Japan, 2014; p. 923. (In Japanese) 
3. Huenges, E. Geothermal Energy Systems: Exploration, Development, and Utilization; WILEY-VCH: Weinheim, Germany, 2010; p. 463.

4. Glassley, W.E. Geothermal Energy: Renewable Energy and the Environment, 2nd ed.; CRC Press: Boca Raton, FL, USA, 2014; p. 381.

5. Arnórsson, S. Isotopic and Chemical Techniques in Geothermal Exploration, Development and Use: Sampling Methods, Data Handling, Interpretation; International Atomic Energy Agency: Vienna, Austria, 2000; p. 351.

6. Arnórsson, S. Geochemistry and geothermal resources in Iceland. In Application of Geochemistry in Geothermal Reservoir Development; UNITAR and UNDP: Rome, Italy, 1991; pp. 145-196.

7. Heneley, R.W.; Ellis, A.J. Geothermal systems, ancient and modern. Earth Sci. Rev. 1983, 19, 1-50. [CrossRef]

8. Rosell, J.B.; Tamboboy, R.J.T.; Sambrano, B.G.; Dacillo, D.B.; Reed, M.H. Mt. Apo fluid evolution: Exploring the role of rock buffers in the reservoir $\mathrm{pH}$ changes with time. In Proceedings of the World Geothermal Congress 2015, Melbourne, Australia, 19-25 April 2015; pp. 1-7.

9. Muraoka, H.; Sakaguchi, K.; Tamanyu, S.; Sasaki, M.; Shigeno, H.; Mizugaki, K. Atlas of Hydrothermal Systems in Japan; Geological Survey of Japan, AIST: Tsukuba, Japan, 2007; p. 110. (In Japanese)

10. Giggenbach, W.F. Geothermal solute equilibria: Derivation of $\mathrm{Na}-\mathrm{K}-\mathrm{Mg}-\mathrm{Ca}$ geoindicators. Geochim. Cosmochim. Acta 1988, 52, 2749-2765. [CrossRef]

11. Arnórsson, S. Processes influencing the $\mathrm{pH}$ of geothermal waters. In Proceedings of the World Geothermal Congress 1995, Firenze, Italy, 18-31 May 1995; pp. 657-962.

12. Muraoka, H. Summary of the heat source distribution investigation. In Trend and Development Technology of Geothermal Power; Science and Technology: Tokyo, Japan, 2011; pp. 125-137. (In Japanese)

13. Geological Survey of Japan, AIST. Volcanoes of Japan, 3rd ed.; Geological Survey of Japan, AIST: Tsukuba, Japan, 2013. (In Japanese)

14. Suzuki, Y.; Ioka, S.; Muraoka, H. Determining the maximum depth of hydrothermal circulation using geothermal mapping and seismicity to delineate the depth to brittle-plastic transition in northern Honshu, Japan. Energies 2014, 7, 3503-3511. [CrossRef]

15. Suzuki, Y.; Ioka, S.; Muraoka, H. Comparative study of the subsurface thermal structure in northern Honshu, Japan, based on normalized temperature data and solute geothermometers. Energies 2016, 9, 382. [CrossRef]

16. Uemura, F.; Saito, M. 1:50,000 Geological Map of Japan, Ohata with Explanatory Text; Geological Survey of Japan: Tokyo, Japan, 1957; p. 31. (In Japanese)

17. New Energy Development Organization (NEDO). Report of Geothermal Development Promotion Survey No. 9, Shimokita Region; New Energy Organization (NEDO): Kawasaki, Japan, 1986; p. 688. (In Japanese)

18. Tomiyama, S.; Umeda, K.; Hanamuro, T.; Takashima, I.; Hayashi, S.; Negishi, Y.; Masudome, Y. Alteration type and thermoluminescence ages of altered rocks in the Mutsu-Hiuchidake volcanic field, Shimokita peninsula, NE Japan. Rocks Miner. Sci. (Ganseki Koubutsu Kagaku) 2007, 36, 111-121. (In Japanese) [CrossRef]

19. Muraoka, H.; Suzuki, Y.; Ioka, S.; Mikami, A.; Kato, K.; Matsuda, M. Finding the Hiuchidake East Slope Fault in Mutsu Hiuchidake Volcano and its significance to the future geothermal exploitation. In Proceedings of the 2014 Annual Meeting Geothermal Research Society of Japan, Hirosaki, Japan, 29-31 October 2014. (In Japanese)

20. Suzuki, Y.; Matsuda, M.; Ioka, S.; Muraoka, H. Structural and geothermal geology on the Hiuchi-dake East Slope Fault in Shimokita Peninsula, Japan. In Proceedings of the 2015 Annual Meeting Geothermal Research Society of Japan, Beppu, Japan, 21-23 October 2015. (In Japanese)

21. Wessel, P.; Smith, W.H.F. New, improved version of the Generic Mapping Tools released. Eos Trans. Am. Geophys. Union 1998, 79, 579. [CrossRef]

22. Henley, R.W. Chemical structure of geothermal systems. In Fluid-Mineral Equilibria in Hydrothermal Systems, Reviews in Economic Geology; Robertson, J.M., Ed.; Society of Economic Geologists: Littleton, CO, USA, 1984; Volume 1, pp. 9-30.

23. Shimada, K. Geochemical modeling (Geochemistry for Geothermal Development). Chinetsu 2000, 3, 36-56. (In Japanese)

(C) 2017 by the authors. Licensee MDPI, Basel, Switzerland. This article is an open access article distributed under the terms and conditions of the Creative Commons Attribution (CC BY) license (http:/ / creativecommons.org/licenses/by/4.0/). 